\title{
Multiple sclerosis causing a partial sixth nerve palsy
}

Kinan Muhammed, Joanna Ball

Department of Neurology, Imperial College Healthcare NHS Trust, London, UK

\section{Correspondence to}

Dr Kinan Muhammed kinan.muhammed@nhs.net

Accepted 12 September 2014

\section{DESCRIPTION}

A 27-year-old man with no significant medical history, presented with right foot weakness and difficulty with balance. MRI of his brain, cervical and thoracic spinal cord showed multiple white matter lesions consistent with demyelination. His cerebrospinal fluid had a white cell count of 27 mononuclear cells and was positive for oligoclonal bands. He was treated with a 3-day course of intravenous methylprednisolone $(1 \mathrm{~g})$ with good resolution of his symptoms. An extensive screen for infective causes was negative and a definitive diagnosis at this time was not made.

Six weeks later he represented with sudden onset painless diplopia and eye movements consistent with a partial right sixth nerve palsy (video 1$)$. He was unable to fully abduct his right eye in the horizontal plane (figure 1A), all other movements were normal (looking left, primary position and looking up; figure $1 \mathrm{~B}, \mathrm{C}$ and $\mathrm{D}$ respectively). A repeat MRI of the brain showed a new lesion in the right ventral pons consistent with the pathway of the

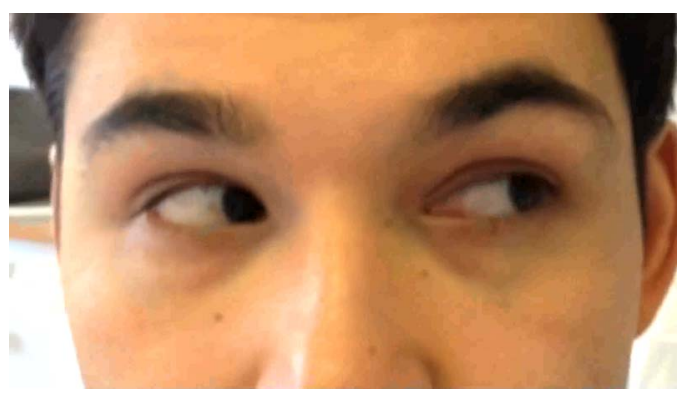

Video 1 Eye movements demonstrating a partial right abducens nerve palsy. right abducens nerve (figure 2; T2-weighted MRI of the brain, axial section through the pons).

This new clinical and radiological finding confirmed a diagnosis of multiple sclerosis. He had a further 3-day course of intravenous methylprednisolone and is now due to start disease modifying treatment (natalizumab). At 8 week follow-up his right-sided partial sixth nerve palsy had resolved and he had no other new neurological symptoms.

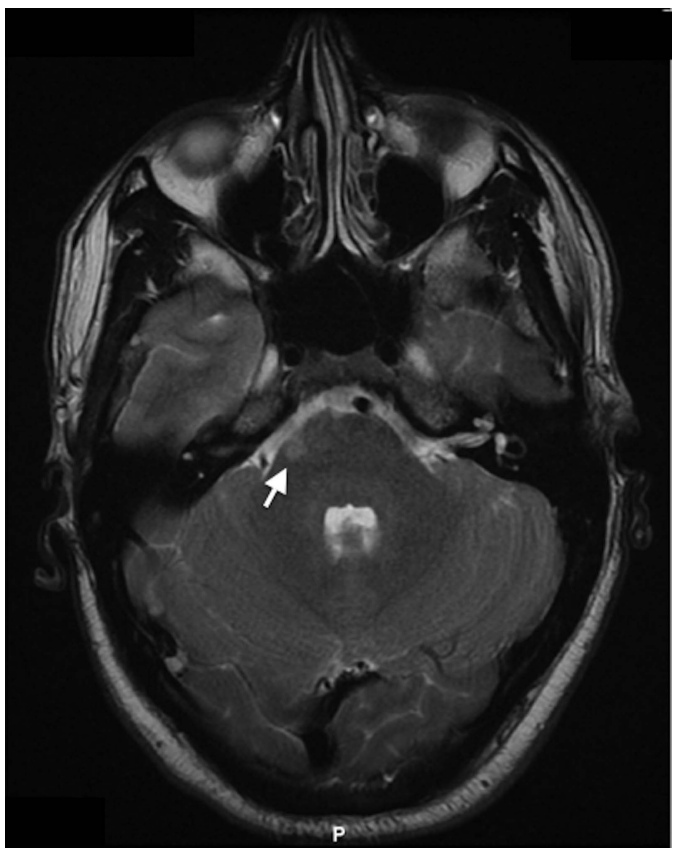

Figure 2 Sclerotic plaque (white arrow) on T2-weighted MRI of the brain, axial section in the right ventral pons consistent with the pathway of the right abducens nerve.
To cite: Muhammed K, Ball J. BMJ Case Rep Published online: [please include Day Month Year] doi:10.1136/bcr-2013201239

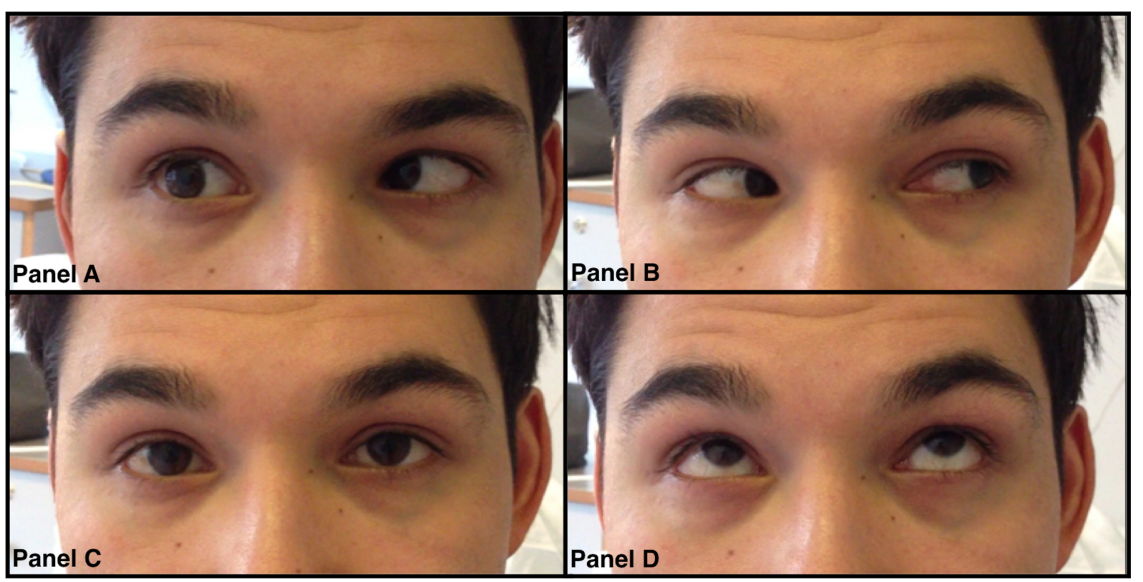

Figure 1 (A) Unable to fully abduct right eye in the horizontal plane on looking to the right. (B) Looking left. (C) Primary position. (D) Looking up. 


\section{Learning points}

- Cranial nerve palsies can be the only sign present in relapses of suspected multiple sclerosis. This correlated with radiological evidence and a reliable history can establish a diagnosis of multiple sclerosis.

- Multiple sclerosis should be included in the differential diagnosis of cranial nerve palsies.

- Accurate examination and anatomical localisation is an important skill in clinical neurology and appropriate imaging should be used to confirm clinical findings.
These images demonstrate that cranial nerve palsies can be the only sign present in relapses of suspected multiple sclerosis ${ }^{1}$ and highlight the importance of accurate examination and localisation in clinical neurology. This is demonstrated by the radiological correlation in the relevant anatomical area of the brain.

Competing interests None.

Patient consent Obtained.

Provenance and peer review Not commissioned; externally peer reviewed.

\section{REFERENCE}

1 Thömke $F$, Lensch $E$, Ringel $K$, et al. Isolated cranial nerve palsies in multiple sclerosis. J Neurol Neurosurg Psychiatry 1997;63:682-5.

Copyright 2014 BMJ Publishing Group. All rights reserved. For permission to reuse any of this content visit http://group.bmj.com/group/rights-licensing/permissions.

BMJ Case Report Fellows may re-use this article for personal use and teaching without any further permission.

Become a Fellow of BMJ Case Reports today and you can:

- Submit as many cases as you like

- Enjoy fast sympathetic peer review and rapid publication of accepted articles

- Access all the published articles

- Re-use any of the published material for personal use and teaching without further permission

For information on Institutional Fellowships contact consortiasales@bmjgroup.com

Visit casereports.bmj.com for more articles like this and to become a Fellow 